\title{
Life cycle theory and dividend payout policy: Evidence from Tehran Stock Exchange
}

\author{
Mohammad Hassani ${ }^{a^{*}}$ and Fatemeh Kazem Pour Dizaji ${ }^{\mathrm{b}}$
}

\begin{abstract}
${ }^{a}$ Assistant Professor, Head of Accounting Department, Management \& Social Science Faculty, Islamic Azad University-Tehran North Branch, Iran ${ }^{b}$ Master in Accounting, Islamic Azad University-Tehran North Branch, Iran

CHRON I CLE

Article history:

Received May 12, 2013

Received in revised format

12 August 2013

Accepted 4 September 2013

Available online

September 62013

Keywords:

Dividend payout policy

Life cycle theory

Tehran Stock Exchange

\section{A B S T R A C T}

This paper investigates the effect of the life cycle theory on explanation of dividend payout policy in Tehran Stock exchange listed companies over the period 2006-2011. For measuring the firm's life cycle, two criteria namely retained earnings to equity ratio and retained earnings to assets ratio have been used as proxies of firm's life cycle. The findings of this research show that only retained earnings to assets ratio has a meaningful and positive effect on dividend payout policy; In the companies that are growing, retained earnings to assets ratio is low; Whereas this ratio is high in the more mature companies and these firms have abundant retained earnings, hence they are good candidates to pay dividends. However, there was no meaningful relationship between another life cycle criteria namely retained earnings to equity ratio and dividend payout policy.
\end{abstract}

\section{Introduction}

Dividend plays essential role on many investment strategies among investors all over the world. Many investors are interested in income investments where firm pays relatively a good dividend per years. On the other hand, some other investors do not consider high dividend payment as a good signal since it shows a small growth rate. In other words, when a firm does not know what do to with profit, a simple way is to pay it back to shareholders and this happens when the firm is getting close to its life cycle. This is associated with life-cycle theory of dividends where the fraction of publicly traded industrial firms that pay dividends is high when the earnings are a big portion of total equity and falls to near zero when most equity is re-invested rather than earned. According to Black (1998) and Jensen (1986), life-cycle influences on the incremental value-relevance of earnings and cash flow measures. DeAngelo et al. (2006) detected a highly significant relationship between the decision to pay dividends and the earned/contributed capital mix, controlling for profitability, growth, firm size, total equity, cash balances, and dividend history. In their regression models, the mix of

*Corresponding author. Tel: +989193007050

E-mail address:m_hassani@iau-tnb.ac.ir (M. Hassani)

(C) 2013 Growing Science Ltd. All rights reserved. doi: $10.5267 / \mathrm{j} . \mathrm{ms} 1.2013 .09 .005$ 
earned/contributed capital had a quantitatively bigger influence than measures of profitability and growth opportunities. They showed that, if well-established firms had not paid dividends, their cash balances could be enormous and their long-term debt trivial, thus granting extreme discretion to managers of these mature firms.

According to Denis and Osobov (2008), in the US, Canada, UK, Germany, France, and Japan, the propensity to pay dividends is larger among bigger, more profitable companies, and those for which retained earnings maintain a large fraction of total equity. According to Fama and French (2001), the proportion of firms paying cash dividends falls from $66.5 \%$ in 1978 to $20.8 \%$ in 1999 , Since there were different changes on characteristics of publicly traded companies. They demonstrated that regardless of their characteristics, firms have become less likely to pay dividends.

Grullon et al. (2002) reported that business units that increase (decrease) dividends may experience a substantial decline (increase) in their systematic risk. They reported that dividend-increasing firms could not increase their capital expenditure and experienced a decline in profitability in the years after the dividend change. The positive market reaction to a dividend increase was associated with the subsequent decline in systematic risk. In the long run, the dividend increasing firms with the largest decline in systematic risk also experienced the largest increase in price over the next three years, implying that the market reaction to dividend changes could not incorporate the full extent of the decline in the expenses of capital associated with dividend changes.

Thanatawee (2011) examined dividend policy of Thai listed firms over the period 2002-2008 and reported that larger and more profitable firms with higher free cash flows and had maintained earnings to equity were more likely to pay higher dividends. Besides, their evidence showed that firms with higher growth opportunities, proxied by market-to-book ratio, were more likely to pay lower dividend payout ratio but higher dividend yield. They provided support for the free cash flow and life-cycle hypotheses and found that financial leverage was positively associated with dividend payouts.

\section{The proposed study}

In this paper, we investigate the effect of the life cycle theory on explanation of dividend payout policy on 152 Tehran Stock Exchange listed companies over the period 2006-2011. For measuring the firm's life cycle, two criteria namely retained earnings to equity ratio and retained earnings to assets ratio have been used as proxies of firm's life cycle. The main hypothesis of this survey is as follows,

Main hypothesis: There is a meaningful relationship between dividend payout policy and life-cycle criteria.

The main hypothesis of this survey consists of two sub-hypotheses as follows,

1. There is a meaningful relationship between the ratio of retained earnings to total equities and dividend payout policy.

2. There is a meaningful relationship between the ratio of retained earnings to total assets and dividend payout policy.

The proposed model of this survey uses the following regression model,

$$
\text { PAYOUT }_{i, t}=\beta_{0}+\beta_{1} \text { RETE }_{i, t}+\beta_{2} \text { RETA }_{i, t}+\beta_{3} R O A_{i, t}+\beta_{4} \operatorname{SIZE}_{i, t}+\beta_{5} A G E_{i, t}+\beta_{6} G O_{i, t}+\beta_{7} L E V_{i, t}+\beta_{8} C H_{i, t}+\beta_{9} C O N C_{i, t}+\varepsilon_{i},
$$

where PAYOUT $_{i, t}$ is a dependent variable, which is dividend payout that is calculated by DPS to EPS ratio (as a proxy of dividend payout policy). $R E T E_{i, t}$ is retained earnings to total equity ratio and $R E T A_{i, t}$ is retained earnings to total assets ratio (as proxies of life cycle), $R O A_{i, t}$ represents return on 
assets ratio (as a proxy of profitability), $S I Z E_{i, t}$ denotes the size of firm, which is calculated by taking the natural logarithm of sales. In addition, $A G E_{i, t}$ denotes the age of firm, which is calculated by taking the natural logarithm of age from establishment, $G O_{i, t}$ represents growth opportunity, $L E V_{i, t}$ shows financial leverage which is calculated by debt to assets ratio, $\mathrm{CH}_{i, t}$ indicates the level of cash holding, which is calculated by cash and short term investment to assets ratio, and finally $C O N C_{i, t}$ is associated with the level of ownership concentration. Table 1 shows some basic statistics associated with the sample data.

\section{Table 1}

The summary of basic statistics

\begin{tabular}{ccccccccccc}
\hline & PAYOUT & RETE & RETA & LEV & ROA & CH & GO & SIZE & AGE & CONC \\
\hline Mean & 0.719375 & 0.311651 & 0.163656 & 0.596651 & 0.179172 & 0.062111 & 0.055820 & 5.649550 & 1.469765 & 0.654170 \\
Median & 0.763844 & 0.381283 & 0.139066 & 0.608774 & 0.155772 & 0.041950 & 0.031610 & 5.554429 & 1.544068 & 0.704800 \\
Maximum & 7.054795 & 0.880713 & 0.717388 & 1.294547 & 0.840500 & 0.515800 & 0.604249 & 8.057836 & 2.155336 & 1.000000 \\
Minimum & 0.000000 & -48.01186 & -0.168075 & 0.056494 & -0.045386 & 0.000900 & -0.215579 & 4.412561 & 0.845098 & 0.000000 \\
Std. Dev. & 0.427829 & 1.797688 & 0.127533 & 0.168941 & 0.115662 & 0.071462 & 0.077187 & 0.622135 & 0.212820 & 0.254055 \\
Skewness & 5.382050 & -26.44420 & 0.996477 & -0.198031 & 1.316841 & 3.213019 & 2.790525 & 0.940520 & -0.709242 & -1.147953 \\
Kurtosis & 75.94251 & 711.3459 & 4.201459 & 3.083642 & 5.818633 & 16.82572 & 14.85702 & 4.363068 & 2.669313 & 3.802496 \\
\hline
\end{tabular}

One of the primary concerns on any regression analysis is that there should not be any strong correlation among independent variables. Table 2 shows details of correlation ratios among various independent variables by using all variables.

Table 2

The summary of correlation among independent variables

\begin{tabular}{|c|c|c|c|c|c|c|c|c|c|}
\hline & RETE & RETA & LEV & ROA & $\mathrm{CH}$ & $\mathrm{GO}$ & SIZE & AGE & $\mathrm{CONC}$ \\
\hline $\begin{array}{c}\text { RETE } \\
\text { (P-Value) }\end{array}$ & 1 & & & & & & & & \\
\hline $\begin{array}{c}\text { RETA } \\
\text { (P-Value) }\end{array}$ & $\begin{array}{c}0.193 \\
(0.000)\end{array}$ & 1 & & & & & & & \\
\hline $\begin{array}{c}\text { LEV } \\
\text { (P-Value) }\end{array}$ & $\begin{array}{l}-0.123 \\
(0.001)\end{array}$ & $\begin{array}{l}-0.492 \\
(0.000)\end{array}$ & 1 & & & & & & \\
\hline $\begin{array}{c}\text { ROA } \\
\text { (P-Value) }\end{array}$ & $\begin{array}{c}0.111 \\
(0.002)\end{array}$ & $\begin{array}{c}0.379 \\
(0.000)\end{array}$ & $\begin{array}{l}-0.431 \\
(0.000)\end{array}$ & 1 & & & & & \\
\hline $\begin{array}{c}\mathrm{CH} \\
\text { (P-Value) }\end{array}$ & $\begin{array}{c}0.049 \\
(0.179)\end{array}$ & $\begin{array}{c}0.291 \\
(0.000)\end{array}$ & $\begin{array}{l}-0.210 \\
(0.000)\end{array}$ & $\begin{array}{c}0.238 \\
(0.000)\end{array}$ & 1 & & & & \\
\hline $\begin{array}{c}\text { GO } \\
\text { (P-Value) }\end{array}$ & $\begin{array}{c}0.020 \\
(0.586)\end{array}$ & $\begin{array}{c}0.156 \\
(0.000)\end{array}$ & $\begin{array}{l}-0.147 \\
(0.000)\end{array}$ & $\begin{array}{c}0.200 \\
(0.000)\end{array}$ & $\begin{array}{c}0.086 \\
(0.018)\end{array}$ & 1 & & & \\
\hline $\begin{array}{c}\text { SIZE } \\
\text { (P-Value) }\end{array}$ & $\begin{array}{c}0.018 \\
(0.612)\end{array}$ & $\begin{array}{c}0.026 \\
(0.466)\end{array}$ & $\begin{array}{c}0.054 \\
(0.136)\end{array}$ & $\begin{array}{c}0.091 \\
(0.012)\end{array}$ & $\begin{array}{c}0.044 \\
(0.228)\end{array}$ & $\begin{array}{c}0.016 \\
(0.656)\end{array}$ & 1 & & \\
\hline $\begin{array}{c}\text { AGE } \\
\text { (P-Value) }\end{array}$ & $\begin{array}{l}-0.007 \\
(0.841)\end{array}$ & $\begin{array}{c}0.053 \\
(0.143)\end{array}$ & $\begin{array}{c}0.014 \\
(0.695)\end{array}$ & $\begin{array}{l}-0.028 \\
(0.446)\end{array}$ & $\begin{array}{l}-0.001 \\
(0.981)\end{array}$ & $\begin{array}{c}0.008 \\
(0.810)\end{array}$ & $\begin{array}{c}0.006 \\
(0.854)\end{array}$ & 1 & \\
\hline $\begin{array}{l}\text { CONC } \\
\text { (P-Value) }\end{array}$ & $\begin{array}{l}-0.042 \\
(0.246)\end{array}$ & $\begin{array}{c}0.040 \\
(0.275)\end{array}$ & $\begin{array}{c}0.038 \\
(0.302)\end{array}$ & $\begin{array}{c}0.115 \\
(0.001)\end{array}$ & $\begin{array}{l}-0.051 \\
(0.165)\end{array}$ & $\begin{array}{l}-0.020 \\
(0.567)\end{array}$ & $\begin{array}{c}0.110 \\
(0.002)\end{array}$ & $\begin{array}{l}-0.244 \\
(0.000)\end{array}$ & 1 \\
\hline
\end{tabular}

The results of Table 2 do not show any strong correlations among independent variables. Therefore, we can do the regression analysis.

\section{The results}

In this section, we present details of regression analysis on Eq. (1) where the results are summarized in Table 3. The results show that F-statistic is within an acceptable limit when the level of significance is five percent. In addition, Durbin-Watson ratio is within an acceptable value, which also specifies that there was no auto-correlation among residuals in regression model. Adjusted RSquare is about 0.32 , which means the regression model is capable of predicting $32 \%$ of the changes on dependent variable. The coefficients of two independent variables, RETE and RETA, are associated with two hypotheses of this survey where the first one is statistically significant and the second one is not. This means that while there is no meaningful relationship between retained earnings to total equity and dividend payout, there is a meaningful relationship between the retained earnings to total assets and dividend payout. In other words, the first sub-hypothesis of this survey was not confirmed while the second sub-hypothesis of the survey has been confirmed. 
Table 3

The summary of regression analysis

\begin{tabular}{|c|c|c|c|c|c|c|}
\hline \multirow[b]{2}{*}{ Independent Variables } & \multicolumn{6}{|c|}{ Dependent Variable: PAYOUT } \\
\hline & (1) & (2) & (3) & (4) & (5) & (6) \\
\hline $\begin{array}{c}\mathrm{C} \\
\text { (P-Value) }\end{array}$ & $\begin{array}{c}0.7145^{\text {*** }} \\
(0.0000)\end{array}$ & $\begin{array}{c}0.1927 \\
(0.7625)\end{array}$ & $\begin{array}{c}0.5965^{* * *} \\
(0.0000)\end{array}$ & $\begin{array}{r}0.4564 \\
(0.5251)\end{array}$ & $\begin{array}{c}0.5964^{\text {***: }} \\
(0.0000)\end{array}$ & $\begin{array}{r}0.4740 \\
(0.5101)\end{array}$ \\
\hline RETE & 0.0029 & 0.0012 & & & -0.0010 & -0.0011 \\
\hline (P-Value) & $(0.3130)$ & $(0.5536)$ & & & $(0.2884)$ & $(0.9075)$ \\
\hline $\begin{array}{c}\text { RETA } \\
\text { (P-Value) }\end{array}$ & & & $\begin{array}{l}0.7288^{* * *} \\
(0.0003)\end{array}$ & $\begin{array}{l}0.8642^{* * *} \\
(0.0026)\end{array}$ & $\begin{array}{l}0.7313^{*} \\
(0.0775)\end{array}$ & $\begin{array}{l}0.8735^{* * *} \\
(0.0025)\end{array}$ \\
\hline LEV & & $-0.3902^{*}$ & & 0.0045 & & 0.0191 \\
\hline (P-Value) & & $(0.0987)$ & & $(0.9838)$ & & $(0.9330)$ \\
\hline $\begin{array}{c}\text { ROA } \\
\text { (P-Value) }\end{array}$ & & $\begin{array}{l}-0.7862^{*} \\
(0.0728)\end{array}$ & & $\begin{array}{c}-0.8592^{* * * *} \\
(0.0004)\end{array}$ & & $\begin{array}{l}-0.8801^{* * * *} \\
(0.0004)\end{array}$ \\
\hline $\mathrm{CH}$ & & -0.1968 & & -0.2915 & & -0.2967 \\
\hline (P-Value) & & $(0.5583)$ & & $(0.4322)$ & & $(0.4247)$ \\
\hline $\begin{array}{c}\text { GO } \\
\text { (P-Value) }\end{array}$ & & $\begin{array}{c}0.3598 \\
(0.2592)\end{array}$ & & $\begin{array}{r}0.3030 \\
(0.2682)\end{array}$ & & $\begin{array}{r}0.3009 \\
(0.2721)\end{array}$ \\
\hline SIZE & & $0.2405^{* *}$ & & 0.1615 & & 0.1592 \\
\hline (P-Value) & & $(0.0474)$ & & $(0.1286)$ & & $(0.1349)$ \\
\hline $\begin{array}{c}\text { AGE } \\
\text { (P-Value) }\end{array}$ & & $\begin{array}{c}-0.2193 \\
(0.6671)\end{array}$ & & $\begin{array}{r}-0.3683 \\
(0.3436)\end{array}$ & & $\begin{array}{r}-0.3781 \\
(0.3317)\end{array}$ \\
\hline CONC & & -0.2228 & & -0.1504 & & -0.1496 \\
\hline (P-Value) & & $(0.2405)$ & & $(0.5037)$ & & $(0.5065)$ \\
\hline $\begin{array}{c}\text { F Stat. } \\
\text { (P-Value) }\end{array}$ & $\begin{array}{c}1.675 \\
(0.0000)\end{array}$ & $\begin{array}{c}1.687 \\
(0.0000)\end{array}$ & $\begin{array}{c}1.798 \\
(0.0000)\end{array}$ & $\begin{array}{c}1.771 \\
(0.0000)\end{array}$ & $\begin{array}{c}1.784 \\
(0.0000)\end{array}$ & $\begin{array}{c}1.735 \\
(0.0000)\end{array}$ \\
\hline D.W. & 1.78 & 1.87 & 1.83 & 1.90 & 1.83 & 1.90 \\
\hline Adj. $R^{2}$ & 0.2969 & 0.3156 & 0.3119 & 0.3262 & 0.3120 & 0.3255 \\
\hline Panel Data & Fixed Effect & Fixed Effect & Random Effect & Fixed Effect & Random Effect & Fixed Effect \\
\hline
\end{tabular}

\section{Conclusion}

In this paper, we have presented an empirical investigation to find the relationship between dividend payout and retained earnings on 152 selected firms in Tehran Stock Exchange. The proposed study has implemented a regression analysis on data and the results of the survey have concluded that while there was some positive and meaningful relationship between retain earnings to total assets and dividend payout, there was not a meaningful relationship between dependent variable and other independent variables such as age, firm size, etc. This means managers of these firms do not follow a unique policy for dividend payout. In fact, there are many evidences that firms' managements initially declare full distribution of profit but finally change their policy to minimum dividend payout.

\section{References}

Black, E. L. (1998). Life-cycle impacts on the incremental value-relevance of earnings and cash flow measures. Journal of Financial Statement Analysis, 4, 40-57.

DeAngelo, H., DeAngelo, L., \& Stulz, R. M. (2006). Dividend policy and the earned/contributed capital mix: a test of the life-cycle theory. Journal of Financial Economics, 81(2), 227-254.

Denis, D. J., \& Osobov, I. (2008). Why do firms pay dividends? International evidence on the determinants of dividend policy. Journal of Financial Economics, 89(1), 62-82.

Fama, E. F., \& French, K. R. (2001). Disappearing dividends: changing firm characteristics or lower propensity to pay?. Journal of Financial economics,60(1), 3-43.

Grullon, G., Michaely, R., \& Swaminathan, B. (2002). Are dividend changes a sign of firm maturity?. The Journal of Business, 75(3), 387-424.

Jensen, M. C. (1986). Agency costs of free cash flow, corporate finance, and takeovers. The American Economic Review, 76(2), 323-329.

Thanatawee, Y. (2011). Life-cycle theory and free cash flow hypothesis: Evidence from dividend policy in Thailand. International Journal of Financial Research, 2(2), p52. 